\title{
Geochemistry of Upper Cretaceous of the Bozeş Formation (Apuseni Mts., Romania) - provenance implications
}

\author{
Luminiţa ZAHARIA ${ }^{1,2, *}$, Ramona BĂLC ${ }^{3}$, Cosmin C. STREMTSAN ${ }^{4}$ and Adriana SOCACIU ${ }^{2}$ \\ 1 Babeş-Bolyai University, Museum of Mineralogy, 1 Mihail Kogălniceanu Street, 400084 Cluj-Napoca, Romania \\ 2 Babeş-Bolyai University, Department of Geology, 1 Mihail Kogălniceanu Street, 400084 Cluj-Napoca, Romania \\ 3 Babeş-Bolyai University, Faculty of Environmental Sciences and Engineering, 30 Fântânele Street, 400294 Cluj-Napoca, \\ Romania \\ 4 University of South Florida, Department of Geosciences, 4202 E. Fowler Avenue, FL33620-8100 Tampa, USA
}

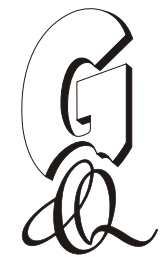

Zaharia, L., Bălc, R., Stremţan, C.C., Socaciu, A., 2016. Geochemistry of Upper Cretaceous of the Bozeş Formation (Apuseni Mts., Romania) - provenance implications. Geological Quarterly, 60 (3): 746-757, doi: 10.7306/gq.1306

\begin{abstract}
A whole-rock geochemical study was carried out on sandstones from the Upper Cretaceous Bozeş Formation in the southeastern part of the Apuseni Mountains (Romania) in order to constrain their provenance and depositional setting. The geochemical results were compared and integrated with previously reported provenance indicators, such as framework composition and heavy mineral assemblages. The chemical composition is similar for all samples investigated, with limited ranges for both major oxides and trace elements. The sandstones are potassic $\left(\mathrm{Na}_{2} \mathrm{O} / \mathrm{K}_{2} \mathrm{O}<1\right)$ and can be classified mainly as arenites with a few greywackes. Their immature to relatively mature character is revealed by the $\mathrm{SiO}_{2} / \mathrm{Al}_{2} \mathrm{O}_{3}$ ratios, ranging between 3.90 and 11.25, as well as their high $\mathrm{Sr} / \mathrm{Rb}$ ratios. The source rocks were affected by weak to moderate chemical alteration, as indicated by the specific index (CIA), with values between 47 and 71 . The detrital material was influenced by a little hydraulic sorting during transportation, while post-depositional effects were limited to K-metasomatism. Two major potential source types were identified based on the chemical composition of the samples studied: a felsic magmatic arc and a recycled, quartzose metasedimentary basement. Our data indicate that the depositional setting is likely to be on a convergent margin. The results are consistent with uplifted and exhumed Transylvanian basement as the major source area.
\end{abstract}

Key words: geochemistry, provenance, Upper Cretaceous, Bozeş flysch, Apuseni Mountains.

\section{INTRODUCTION}

As material eroded from active tectonic regions and subsequently stored in adjacent basins, sediments are typically an archive of the geological history of an area from both tectonic and geodynamic points of view. The mineralogical and geochemical composition of sedimentary rocks reflects the characteristics of their source areas, as well as the processes that affected the detrital material during transport and deposition, through weathering, sorting, recycling and diagenesis (Bhatia, 1983). Many analytical approaches, e.g. based on modal distribution of detrital grains, heavy mineral assemblages, bulk rock geochemical composition or mineral geochemistry are applied in provenance studies, each one with its own advantages and disadvantages (e.g., von Eynatten and Gaupp, 1999; Weltje and von Eynatten, 2004). Among these, major and trace element whole-rock analysis is widely applied to reconstruct the geodynamic setting of sedimentary basins, as each plate tectonic configuration results

\section{* Corresponding author, e-mail: luminita.zaharia@ubbcluj.ro}

Received: October 9, 2015; accepted: April 9, 2016; first published online: August 22, 2016 in diverse tectono-magmatic suites with different chemical characteristics, transferred to the subsequent sedimentary rocks (Bhatia, 1983; Roser and Korsch, 1988).

Part of the Alps-Carpathians-Dinarides chain, Apuseni Mts. is the result of collision between the Tisia and Dacia continental blocks during the Cretaceous, due to the closure of the Transylvanian Ocean (East Vardar Ocean after Schmid et al., 2008), part of the Tethys Ocean (Săndulescu, 1975). The Apuseni Mountains consist of three major tectonic units: the Bihor Unit (Autochthon), the Apusenides (also known as the Internal Dacides) and the Western Transylvanides (Săndulescu, 1984, 1994; Balintoni, 1994, 1997). The Bihor Autochthon represents the basement unit, and it is composed of metamorphic rocks and Variscan granites, partially overlain by a Permo-Mesozoic sedimentary cover. As a result of Transylvanian Ocean subduction, basement-cover nappes were emplaced during the Mid-Cretaceous, and constitute the Western Transylvanides and Apusenides. Following Mid-Cretaceous thrusting, deep marine sedimentary deposition occurred, with siliciclastic successions being described as Gosau-type deposits, similar to the Gosau Group from the Eastern Alps (Willingshofer et al., 1999; Schuller, 2004; Schuller et al., 2009). The Bozeş Formation and the Gosau-type units from the Apuseni Mts. are interpreted as a post-tectonic cover of the obducted basement-cover nappes (Săndulescu, 1984). 
The Upper Cretaceous sedimentary units of the Apuseni Mts., such as the Bozeş Formation, are of a special importance in deciphering the geodynamic history of the area, as they are a key feature of the tectonics throughout the Alpine-Carpathian-Pannonian region (Willingshofer et al., 1999). This is the first study in which the whole-rock geochemical composition of the Bozeş sandstones is determined and used to constrain the sediment provenance, in order to add new data to the basinal history of an important unit.

\section{GEOLOGICAL BACKGROUND}

In the southern part of the Apuseni Mts., only Jurassic and Lower Cretaceous volcanic rocks and associated sedimentary deposits of the Western Transylvanides and several nappe systems (Biharia and Codru) belonging to the Apusenides occur, together with other units such as Jurassic granitoids, Cretaceous flyschoid or Gosau-type deposits, as well as Upper Cretaceous-Paleogene and Neogene extensional magmatites (Balintoni, 1997; Fig. 1).

The Bozeş Formation crops out in the southeastern part of the Apuseni Mts., and is represented by a Santonian-Campanian turbidite-type sedimentary sequence, consisting mainly of grey sandstones and silty marls, with microconglomeratic levels in the upper part and having an estimated thickness of $3000 \mathrm{~m}$ (Dimian and Popa-Dimian, 1964; Tomescu et al., 1969; Marincaș and Mânecan, 1971; Marincaş, 1973; Bălc et al., 2007, 2012). The Bozeş Formation is considered as a part of the Western Transylvanides in the Apuseni Mts. (e.g., Ghiţulescu and Socolescu, 1941; Bleahu et al., 1981), and its tectonic evolution is connected with the neighbouring, much larger, Transylvanian Basin, a post-Cenomanian sedimentary basin developed on the top of Middle Cretaceous basement nappes (Krézsek and Bally, 2006).

There are few studies of the basinal history of the Bozeş unit, and these refer mainly to the provenance. These studies often made use of sedimentary and petrographic observations to order to identify the transport direction of the detrital material (e.g., Antonescu et al., 1963; Dimian and Popa-Dimian, 1964), heavy minerals for unravelling the source rock type (Pojar et al., 2014), or basinal modelling based on vitrinite reflectance in order to establish the depositional setting (Schuller, 2004).

\section{SAMPLES AND ANALYTICAL METHODS}

For petrographic and geochemical investigations, twenty samples of fine- to medium-grained sandstones, considered as representative, were collected from various exposures along the numerous valleys which cut the Bozes Formation (Fig. 2).

Petrographic investigation was carried out by means of optical microscopy on thin sections for all twenty samples. Of these, for thirteen samples, framework petrography was performed according to the Gazzi-Dickinson method (e.g., Dickinson, 1970; Ingersoll et al., 1984). Point-counting was performed on 300 grains per sample, while the cement was excluded.

For geochemical investigations, the rock samples were crushed and pulverized to powder in agate mortars. Fifteen samples were analysed for major elements at the Department of Lithospheric Research, University of Vienna, Austria, using a Phillips PW 2400 sequential X-ray Fluorescence (XRF) spectrometer on fusion glasses with a 1:5 samples to lithium metaborate flux ratio. For the same samples, trace elemental compositions were determined by means of inductively coupled plasma-mass spectrometry (ICP-MS) at the University of South Florida's Center for Geochemical Analysis, Tampa, USA. Sample preparation was based on the lithium metaborate fluxed fusion procedure of Kelley et al. (2003). An additional five samples were analysed at ACME Analytical Laboratories Ltd., Vancouver, Canada, using X-ray fluorescence and ICP-MS, respectively, following a lithium metaborate-tetraborate fusion. Accuracy for all determinations is $1 \%$ for major elements and within $3-5 \%$ for most of the trace elements.

\section{PETROGRAPHIC RESULTS}

\section{PETROGRAPHIC COMPONENTS}

The samples studied are clast-supported, poorly-sorted, massive sandstones, with carbonate cement. The main minerals include quartz, feldspars and micas, with accessory phases such as zircon, garnet, and iron oxides and hydroxide. A consistent quantity of lithic fragments is also present. The clasts are likely sourced from provenance areas outside the depositional basin. Based on petrographic observations, the Bozes samples studied can be classified as lithic arenites.

Detrital quartz occurs in all samples as subrounded to angular, colourless monocrystalline grains, with either undulatory or non-undulatory extinction. Very rare chert fragments were observed. Feldspars are quantitatively subordinate to quartz, the grains being often slightly rounded and quite fresh, with only a few signs of alteration (mainly sericitisation). They are represented by plagioclase, with good polysynthetic twinning, and $\mathrm{K}$-feldspar, mainly as microcline. Minerals from the mica group include laths of biotite and muscovite, characteristic for all samples, but a few grains of reworked glauconite were identified in some of the samples studied. Biotite is more abundant than white mica in most of the samples.

Lithic clasts are dominated by fragments of metamorphic and volcanic rocks, sedimentary rocks being scarce. Metamorphic rocks are the major lithic constituents of the samples, and are represented mainly by quartzite, together with a few gneiss or extremely rare micaschist fragments. Volcanic fragments are the major lithics only in a few samples, and consist of microphenocrysts, mainly of feldspar, within a fine-grained or glassy groundmass. Sedimentary rock fragments are scarce, and observed only in coarse-grained samples; they include sandstone grains and a very few siltstone fragments.

Bioclastic detritus consists exclusively of skeletal grains. Easily recognizable, subangular to subrounded bioclasts appear frequently, and include fragments of small planktonic and benthic foraminifers, red algae, radiolaria, and rare bivalves. Cement is formed by micrite and sparry calcite, and constitutes between 15 and $30 \%$ of all samples.

\section{MODAL COMPOSITION}

The framework mineralogy was identified by counting parameters such as monocrystalline quartz $(\mathrm{Qm})$, polycrystalline quartz (Qp, including the quartzite fragments and the occasional chert fragments), total feldspars $(F)$, all micas $(M)$, volcanic lithics (Lv), sedimentary lithics (Ls) and metamorphic lithics ( $\mathrm{Lm}$, including the rare gneiss and micaschist fragments, but not the quartzite), opaque minerals $(\mathrm{O})$, and other phases (Misc). Cement was not counted. The calculated parameters were $Q$ as total quartz $(Q=Q m+Q p)$, $L$ as the sume of lithics $(L=L v+L s+L m)$ and $L t$ as total lithics $(L t=L+Q p)$. Raw data 


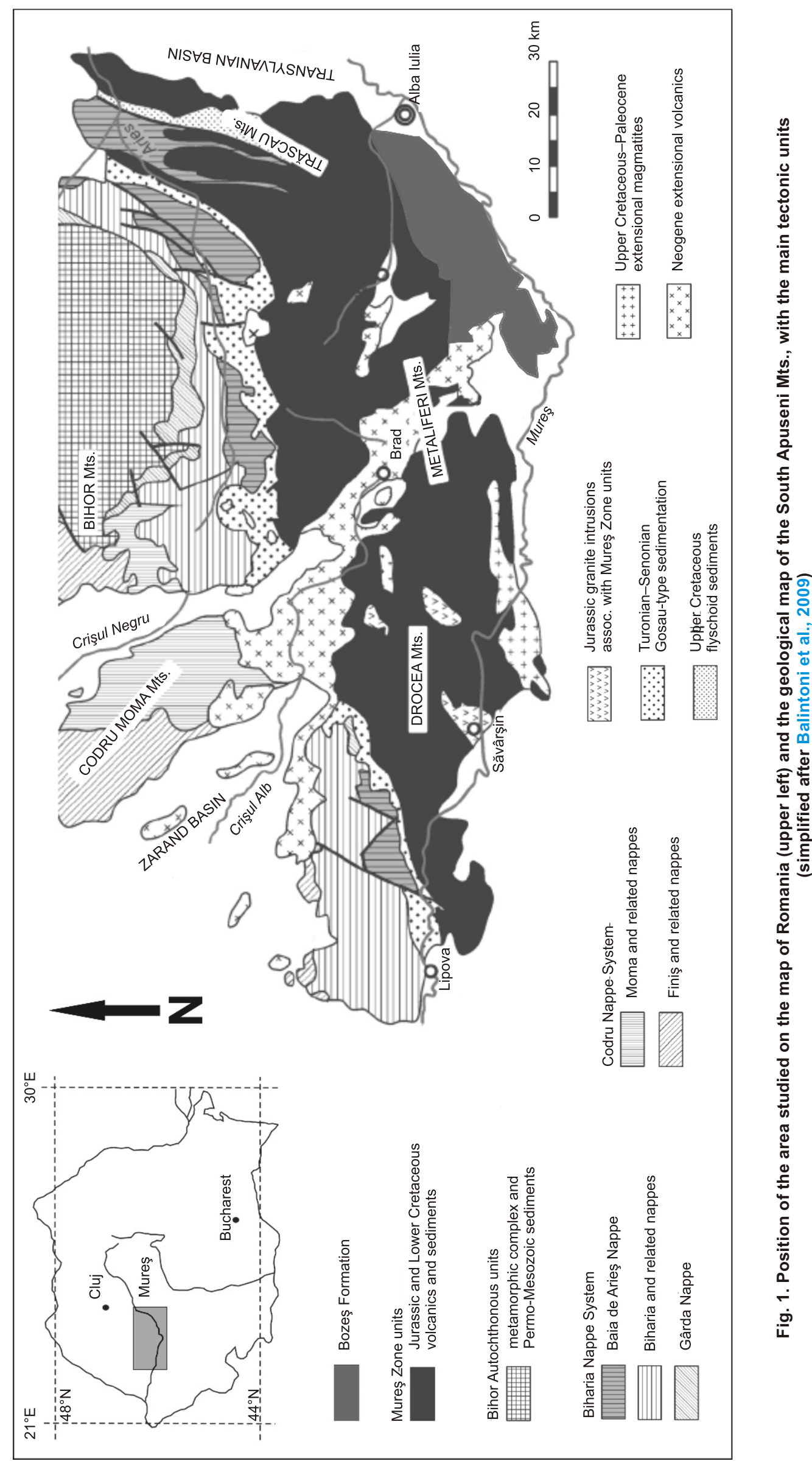




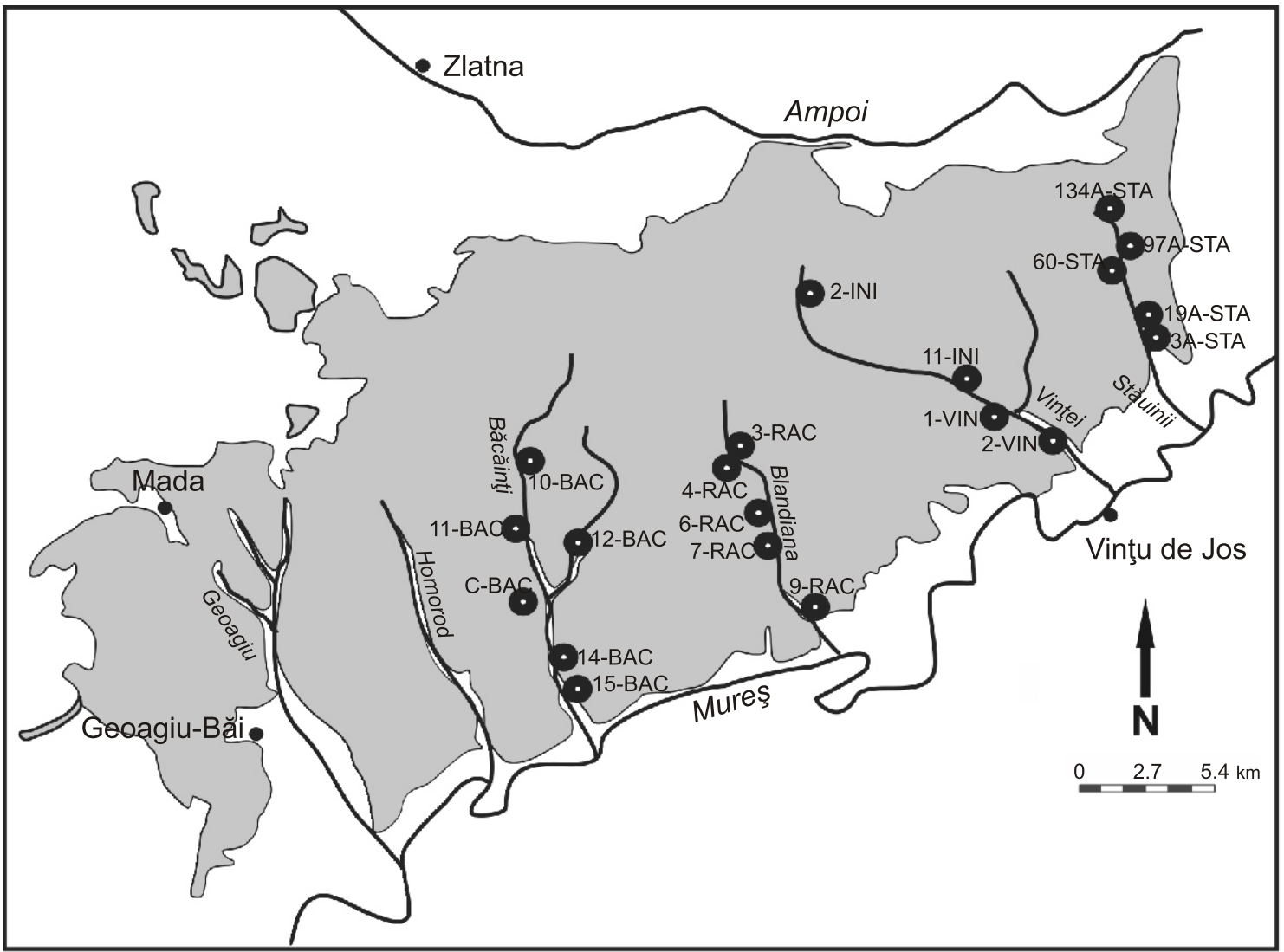

Fig. 2. Location of the samples studied within the Bozeş Formation (modified after Pojar et al., 2014)

expressed as percentage and calculated framework parameters are listed in Appendix $1^{*}$. The Bozeş sandstones are dominated by framework quartz $(40-56.67 \%)$, while the lithics (12.67-24\%) and feldspars (11.76-17\%) are subordinate, but in almost equal quantities. Monocrystalline quartz (25-37.33\%) dominates over polycrystalline quartz (12.33-21.67\%). The relatively large amount of quartz compared to the other unstable components, such as feldspars or lithics (up to two times higher) indicates that the Bozeş sandstones reached some degree of compositional maturity.

The two framework composition provenance diagrams of Dickinson (Dickinson and Suczek, 1979; Dickinson, 1985) and revised by Weltje (2006) were applied to the Bozeş unit, using also data from the literature (Antonescu et al., 1963; Suciu-Krausz et al., 2006). None of the cited studies provides the raw data, therefore the results they provide were used for different diagrams: QFL (quartz-feldspars-lithics) for data from Suciu-Krausz et al. (2006), while for those of Antonescu et al. (1963), which included the quartzite fragments within the counted quartz, QmFLt (monocrystalline quartz-feldpars-total lithics) was involved. Based on both, our own data and those from the literature, the Bozeş sedimentary samples show a wide spread throughout the fields of active magmatic (undissected, transitional and dissected) arcs, as well as within the recycled orogen field (Fig. 3). Considering only the re-evaluated fields after Weltje (2006), the Bozeş samples are more typical of a recycled orogen provenance, with only a few sedimentary samples displaying a magmatic arc signature.

\section{WHOLE-ROCK GEOCHEMICAL RESULTS}

Major and trace elemental composition of all samples investigated from the Bozeş Formation is shown in Appendix 2. The sedimentary rocks are characterized by a relatively wide $\mathrm{SiO}_{2}$ content (53.39-79.82 wt.\%, average $64.92 \mathrm{wt} . \%)$, and rather limited $\mathrm{MgO}(0.82-2.24$ wt. $\%$, average $1.34 \mathrm{wt} . \%)$. They are predominantly potassic $\left(\mathrm{Na}_{2} \mathrm{O} / \mathrm{K}_{2} \mathrm{O}<1\right)$, with low contents of $\mathrm{Na}_{2} \mathrm{O}$ (0.81-2.08 wt.\%, average 1.43 wt. \%) and $\mathrm{K}_{2} \mathrm{O}(1.36-2.49$ wt. \%, average $1.84 \mathrm{wt} . \%)$, respectively. The compositional ranges of the remaining major elements are $\mathrm{Fe}_{2} \mathrm{O}_{3}(1.60-5.55$ wt. \%), $\mathrm{MnO}$ (0.03-0.25 wt.\%), $\mathrm{CaO}\left(1.21-19.16 \quad\right.$ wt. \%), $\mathrm{TiO}_{2}$ (0.27-0.74 wt.\%) and $\mathrm{P}_{2} \mathrm{O}_{5}$ (0.05-0.17 wt.\%).

Reflecting the ratio of quartz to clay and feldspar minerals, and therefore indicating the maturity of the sedimentary rock, the $\mathrm{SiO}_{2} / \mathrm{Al}_{2} \mathrm{O}_{3}$ values of Bozes sandstones are between 3.90 and 11.25. The $\mathrm{K}_{2} \mathrm{O} / \mathrm{Na}_{2} \mathrm{O}$ ratio, which is a proxy for the effects of provenance and diagenesis, and indicating the quantity of K-feldspar and mica versus albite-rich plagioclase, has values between 0.76 and 2.62 for the Bozeş siliciclastic rocks. The diagram of Pettijohn et al. (1972), which makes use of $\mathrm{SiO}_{2} / \mathrm{Al}_{2} \mathrm{O}_{3}$ and $\mathrm{Na}_{2} \mathrm{O} / \mathrm{K}_{2} \mathrm{O}$ logarithmic ratios to distinguish between different types of sediment lithologies, classifies the Bozeş rocks mainly as litharenites, with a few greywackes (Fig. 4A), in accordance with the petrographic observations.

The Bozes siliciclastic rocks are characterized by a limited range of trace element contents with few exceptions such as $\mathrm{Cr}=23.95-196.40 \mathrm{ppm}$ and $\mathrm{Ni}=8.87-2827.99$ ppm (Appen-

* Supplementary data associated with this article can be found, in the online version, at doi: $10.7306 / \mathrm{gq} .1306$ 


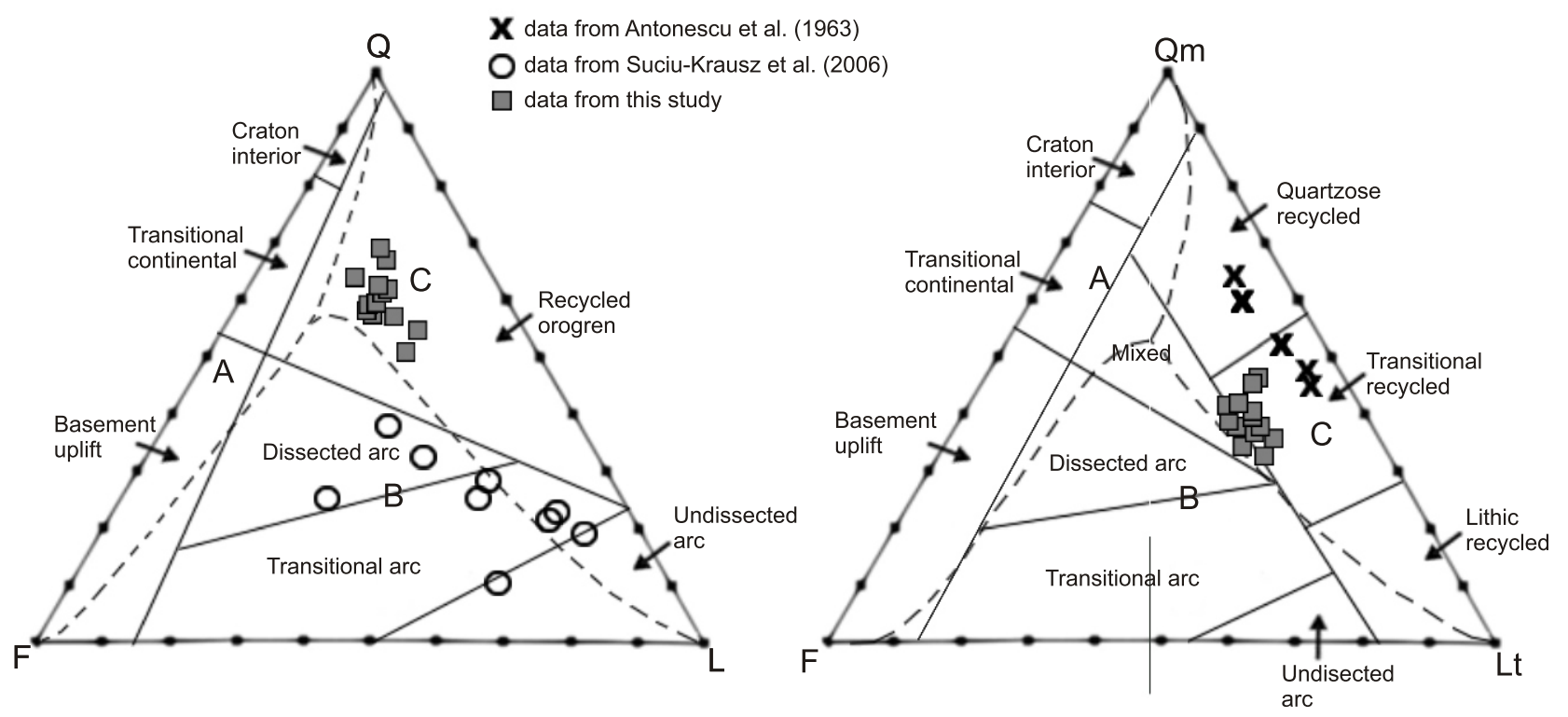

Fig. 3. QFL (quartz-feldspars-lithics) and QmFLt (monocrystalline quartz-feldspars-total lithics) provenance diagrams (after Dickinson, 1985) for the Bozeş sediments, including data from Antonescu et al. (1963) and Suciu-Krausz et al. (2006)

Dotted lines mark the re-evaluated provenance fields after Weltje (2006): A - continental block provenance, B - magmatic arc provenance and $\mathrm{C}$ - recycled orogen provenance
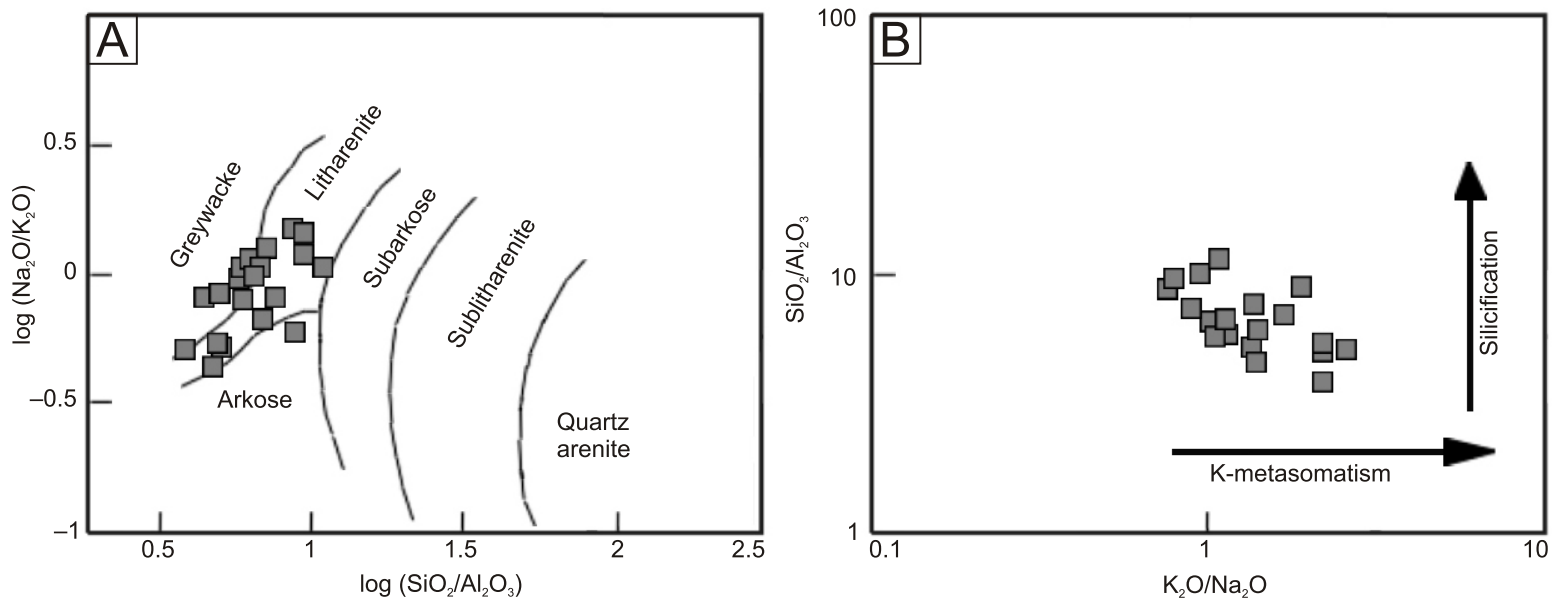

Fig. 4A - classification diagram based on major elements for the Bozeş sedimentary rocks (after Pettijohn et al., 1972); B - discrimination diagram for post-depositional alteration processes which affected the Bozeş siliciclastic rocks (after Long et al., 2008)

dix 2). The trace element values are in most cases almost similar to those of the average upper continental crust (UCC; Taylor and McLennan, 1985; Fig. 5A), with depletion in Nb and Ta content relative to UCC values, which is a feature of sediments derived from continental sources (Williams et al., 2009).

A relatively uniform distribution of REE in detrital rocks is interpreted as a result of homogenization during sedimentary processes. REE are generally considered to be immobile, with only minor changes during sedimentation processes (Taylor and Mclennan, 1985). The Bozeş sandstones show very little variation of $\Sigma R E E$, between 60 and $143 \mathrm{ppm}$, lower or equal to UCC value ( 143; Taylor and McLennan, 1985). On a chondrite-normalized REE diagram (McDonough and Sun,
1995), the samples show similar fractionation patterns, resembling the average Post-Archean Australian Shale (PAAS) composite, which represents the post-Archean upper continental crust (Taylor and McLennan, 1985; Fig. 5B). All samples are enriched in light rare earth elements (LREE), with La to Pr contents averaging almost 100 times those of chondrite. The heavy rare earth elements (HREE) are not as enriched as LREE, but are still up to 10 times chondrite values. The Eu anomaly is usually interpreted in sedimentary rocks as being inherited from igneous source rocks (McLennan and Taylor, 1991; Taylor and McLennan, 1985), and the Bozeş sandstones analysed are characterized by a weak negative Eu anomaly, with values from 0.66 to 0.80 (Appendix 2). 

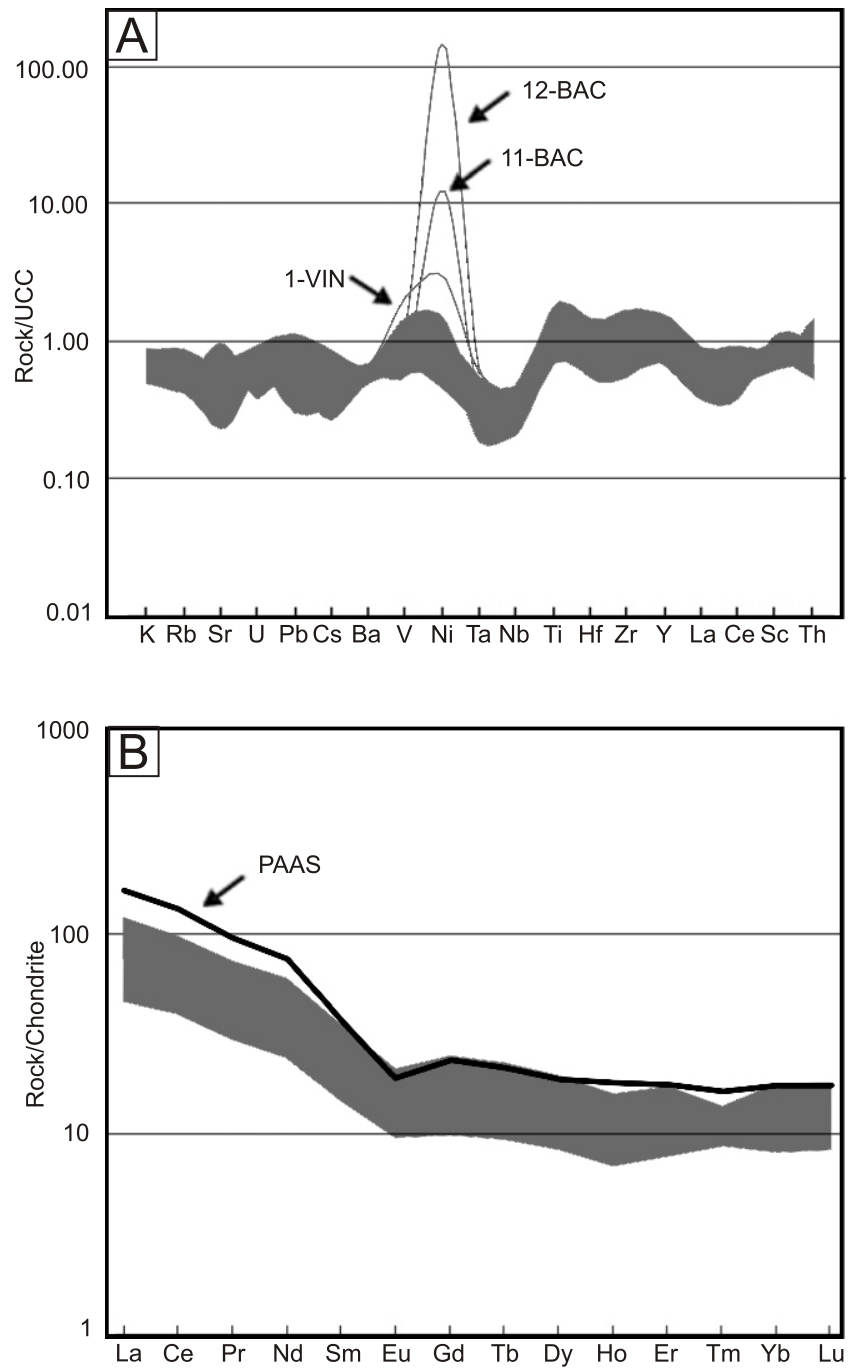

Fig. 5A - upper continental crust (UCC; after Taylor and McLennan, 1985) - normalized multi-element spider diagram for the Bozeş sedimentary rocks (as compositional range), the most notable outlier samples in the case of the $\mathrm{Ni}$ content are shown; B - chondrite-normalized REE (McDonough and Sun, 1995) patterns for the Bozeş sedimentary rocks (as compositional range), the composition of average Post-Archean Australian Shale (PAAS; after McLennan, 1989) is shown for comparison

\section{INTERPRETATION OF GEOCHEMICAL DATA}

The geochemical signatures of sedimentary rocks can be severely influenced by surficial alteration of the source rocks and by climatic and weathering conditions during the transport and deposition of the eroded material, as well as by post-depositional processes (McLennan et al., 1993). Therefore, it is important to evaluate the possible influence of factors such as alteration, sorting or diagenesis in order to use the geochemical data for interpreting the provenance and depositional setting of the Bozeş sandstones.

\section{SOURCE AREA WEATHERING AND SEDIMENT MATURITY}

Chemical weathering of the source rocks has a large influence on the major element geochemistry of the resulting siliciclastic material (Nesbitt and Young, 1982, 1984; McLennan et al., 1993; Fedo et al., 1995). To quantitatively evaluate the degree of chemical weathering and alteration, the chemical index of alteration (CIA; Nesbitt and Young, 1982; Fedo et al., 1995) and chemical index of weathering (CIW; Harnois, 1988) are commonly applied. These are calculated using the molar proportions: $\mathrm{CIA}=\left[\mathrm{Al}_{2} \mathrm{O}_{3} /\left(\mathrm{Al}_{2} \mathrm{O}_{3}+\mathrm{CaO}^{*}+\mathrm{Na}_{2} \mathrm{O}+\mathrm{K}_{2} \mathrm{O}\right)\right] \cdot 100$ and $\mathrm{CIW}=\left[\mathrm{Al}_{2} \mathrm{O}_{3} /\left(\mathrm{Al}_{2} \mathrm{O}_{3}+\mathrm{CaO}^{*}+\mathrm{Na}_{2} \mathrm{O}\right)\right] \cdot 100$, where $\mathrm{CaO}^{*}$ represents the $\mathrm{CaO}$ in the silicate fraction only, calculated according to the methods of McLennan (1993) and Fedo et al. (1995). High CIA and CIW values (over 80) are considered to be the result of the removal of labile cations (such as $\mathrm{Ca}^{2+}, \mathrm{Na}^{+}$, $\mathrm{K}^{+}$) and enrichment in the stable residual elements (such as $\mathrm{Al}^{3+}, \mathrm{Ti}^{4+}$ ) during weathering and alteration; conversely, low CIA and CIW values (up to 50) are characteristic of little or no chemical alteration (Nesbitt and Young, 1982, 1984; Harnois, 1988; Fedo et al., 1995). The CIA values of the Upper Cretaceous Bozeş sandstones range from 47 to 71 (mean 60; Appendix 2), indicating low to mainly moderate degrees of alteration in the source areas. The CIW-index of the Bozeş sedimentary rocks ranges from 53 to 82 (mean 68; Appendix 2), also suggesting a moderate to high degree of weathering.

As CIA and CIW index values may result in misleading conclusions for samples with highly variable $\mathrm{CaO}$ contents, Cullers (2000) proposed a modified index which excludes the $\mathrm{CaO}$ content: CIW' $=\left[\mathrm{Al}_{2} \mathrm{O}_{3} /\left(\mathrm{Al}_{2} \mathrm{O}_{3}+\mathrm{CaO}^{*}+\mathrm{Na}_{2} \mathrm{O}\right)\right] \cdot 100$. For the Bozeş sandstone samples, the CIW' index has values between 69 and 90 (mean 80), which can be interpreted as indicating a moderate to high weathering degree of the source rocks (Appendix 2), in agreement with the previously discussed chemical indices.

Being sensitive to weathering processes, the $\mathrm{SiO}_{2} / \mathrm{Al}_{2} \mathrm{O}_{3}$ ratio is a significant parameter indicating the maturity of sedimentary rocks (Roser and Korsch, 1986; Roser et al., 1996). Average $\mathrm{SiO}_{2} / \mathrm{Al}_{2} \mathrm{O}_{3}$ values in unaltered igneous rocks range from $\sim 3.0$ (basic) to $\sim 5.0$ (acidic), while values $>5.0$ in sediments are an indication of progressive maturity (Roser et al., 1996). This ratio increases as quartz survives preferentially relative to feldspars and lithic fragments. The $\mathrm{SiO}_{2} / \mathrm{Al}_{2} \mathrm{O}_{3}$ values of Bozeş sandstones are between 3.90 and 11.25 , indicating a low to moderate sediment maturity, as shown also by the relatively large quantity of feldspar and lithics. The high $\mathrm{Sr} / \mathrm{Rb}$ ratios (1.27-6.84), all above unity, indicate that Sr-rich feldspars in the original sediment had undergone little transformation into (normally Rb-rich) clay minerals, a feature of relatively immature and ill-sorted sediments (Winchester et al., 2003).

\section{EFFECTS OF HYDRAULIC SORTING ON CHEMICAL COMPOSITION}

During sediment transport and deposition, hydraulic sorting can cause enrichment in weathering-resistant minerals, such as zircon, monazite, titanite, garnet or apatite (Nesbitt and Young, 1996). As these minerals are the main hosts for some trace and rare earth elements, their preferential accumulation may result in irregular chemical variation of such chemical elements (e.g., Zr, Y, Nb, Ta, Gd, Yb; McLennan et al.,1990). The abundances of $\mathrm{P}_{2} \mathrm{O}_{5}, \mathrm{Y}, \mathrm{Nb}$ or $\mathrm{Ta}$ are relatively constant for the Bozeş sandstones, and a heavy mineral accumulation is excluded by their correlation indices with $\mathrm{SiO}_{2}$, which are very low in all cases (between 0.02 and 0.3).

The $\mathrm{Gd}_{N} / \mathrm{Yb}_{\mathrm{N}}$ ratio ranges between 1.0 and 2.0 in most upper crustal igneous rocks and post-Archean sedimentary deposits, while only slight enrichment in monazite in sediments will result in a high increase of this ratio (up to 3.0 or more, McLennan et al., 1993). The Bozeş sedimentary samples possess relatively low $\mathrm{Gd}_{N} / \mathrm{Yb}_{N}$ ratios (1.11-1.62; Appendix 2) in the range of upper crustal rocks, which points to no enrichment in monazite. 
The Zr content (103-322 ppm), for some samples higher than PAAS (210 ppm, McLennan et al., 1983) or UCC (190 ppm, Taylor and McLennan, 1985) values, might indicate some zircon addition, which may cause enrichment in Th and HREEs too (Cullers et al., 1987). There is a relatively weak correlation for $\mathrm{Zr}$ versus Th $(r=0.49)$ and $\mathrm{Zr}$ versus $\Sigma$ HREEs $(r=0.57)$ for the Bozeş samples, attesting that zircon has a little influence over the abundances of these elements, but a positive and high correlation coefficient $(r=0.91)$ for $\mathrm{Zr}$ and $\mathrm{Hf}$, due to their similar behavior. However, due to the resistance of zircon to chemical weathering and erosion, Zr enrichment may occur not only because of hydraulic sorting, but also through recycling processes of an old sedimentary source, possibly metamorphosed (McLennan et al., 1993).

Therefore, it can be interfered that heavy mineral accumulation is not significant in the case of the Bozeş samples. This is also supported by the relatively short distance of detritus transportation as inferred by the presence of angular to subangular lithic and quartz grains, as well as by the relatively high quantity of feldspar.

\section{EFFECTS OF DIAGENESIS ON CHEMICAL COMPOSITION}

Post-depositional alteration can drastically alter the geochemistry of sedimentary rocks. Among the most important diagenetic processes to evaluate are silicification and K-metasomatism (Fedo et al., 1995), which might result from hydrothermal metasomatism or syndepositional interaction with seawater at low temperatures (Van Kranendonk, 2006, and references therein). Such post-depositional processes could cause leaching of $\mathrm{Ca}, \mathrm{Mg}$ and $\mathrm{Na}$, and enrichment in $\mathrm{Si}$ and $\mathrm{K}$ (Cullers et al., 1993). Minor post-depositional silicification and some degree of $\mathrm{K}$-metasomatism are revealed by the $\mathrm{K}_{2} \mathrm{O} / \mathrm{Na}_{2} \mathrm{O}$ and $\mathrm{SiO}_{2} / \mathrm{Al}_{2} \mathrm{O}_{3}$ ratios of the Bozeş deposits (Fig. 4B).

Redistribution of alkalis during diagenesis can be evaluated also using the A-CN-K $\left[\mathrm{Al}_{2} \mathrm{O}_{3}-\left(\mathrm{CaO}{ }^{*}+\mathrm{Na}_{2} \mathrm{O}\right)-\mathrm{K}_{2} \mathrm{O}\right]$ and A-CNK-FM $\left[\mathrm{Al}_{2} \mathrm{O}_{3}-\left(\mathrm{CaO}^{*}+\mathrm{Na}_{2} \mathrm{O}+\mathrm{K}_{2} \mathrm{O}\right)-\left(\mathrm{FeO}{ }^{*}+\mathrm{MgO}\right)\right]$ triangular diagrams after Nesbitt and Young (1989) and Camiré et al. (1993), where $\mathrm{CaO}^{*}$ represents the calcium oxide accommodated only in silicates and $\mathrm{FeO}^{*}$ the total iron oxide content. In the A-CN-K diagram the Bozeş sandstones define a trend which is not parallel to the $\mathrm{CN}-\mathrm{K}$ line (Fig. 6), implying that $\mathrm{K}$-metasomatism may have been a factor in affecting the composition of the sedimentary rocks (McLennan et al., 1993; Fedo et al., 1997). In the A-CNK-FM diagram (Fig. 7), no clear trend can be observed, all samples being positioned close to the igneous rocks line, though around the trend towards an ideal illite and muscovite composition, which points to the same K-metasomatism. K-addition during deposition and diagenesis is also supported by the presence of rare glauconite grains.

\section{SOURCE ROCK COMPOSITION AND MATERIAL RECYCLING}

Geochemical parameters, including major elements as well as selected trace elements, have been widely used to discriminate the source composition for detrital sedimentary rocks (Bhatia, 1983; Roser and Korsch, 1985, 1986, 1988; Bhatia and Crook, 1986). However, discrimination diagrams based on the abundance of some elements, such as $\mathrm{Na}$ or K, must be treated with caution, because of their high mobility during depositional processes (e.g., Wronkiewicz and Condie, 1987; McLennan et al., 1993, 2003). In contrast, the abundance of some elements,

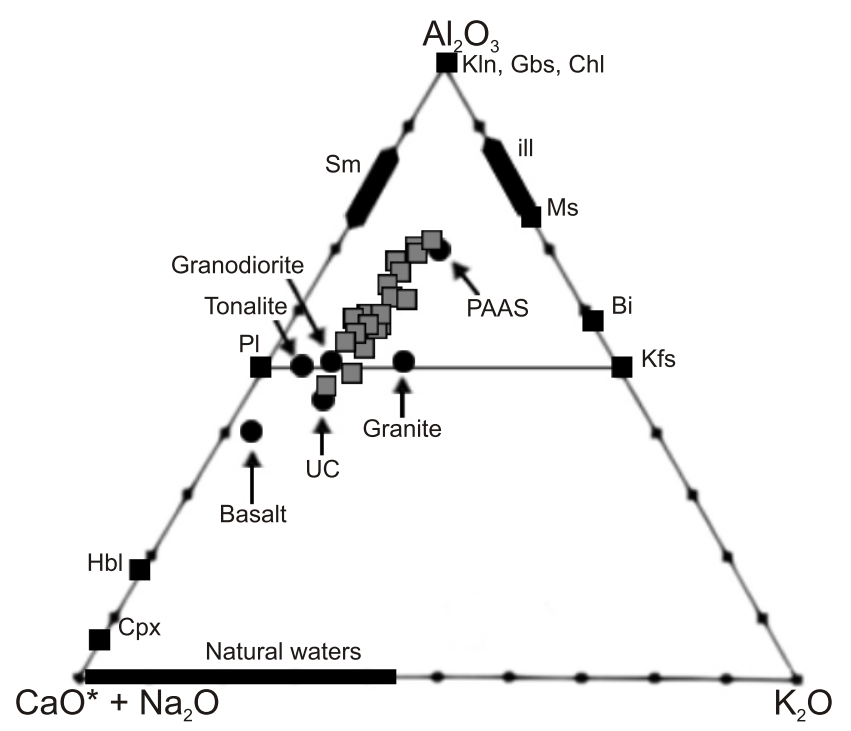

Fig. 6. A-CN-K (CIA) ternary diagram (mol \%) showing composition of the Bozeş sediments (after Nesbitt and Young, 1982)

Data for tonalite, granodiorite, granite are from Condie (1993); average upper crust (UC) is from Taylor and McLennan (1985); Post-Archean Australian Shale (PAAS) data is after McLennan (1989); Bi - biotite, Chl - chlorite, Cpx - clinopyroxene, Gbs gibbsite, Hbl - hornblende, ill - illite, Kfs - K-feldspar, Kln kaolinite, Ms - muscovite, PI - plagioclase, Sm - smectite

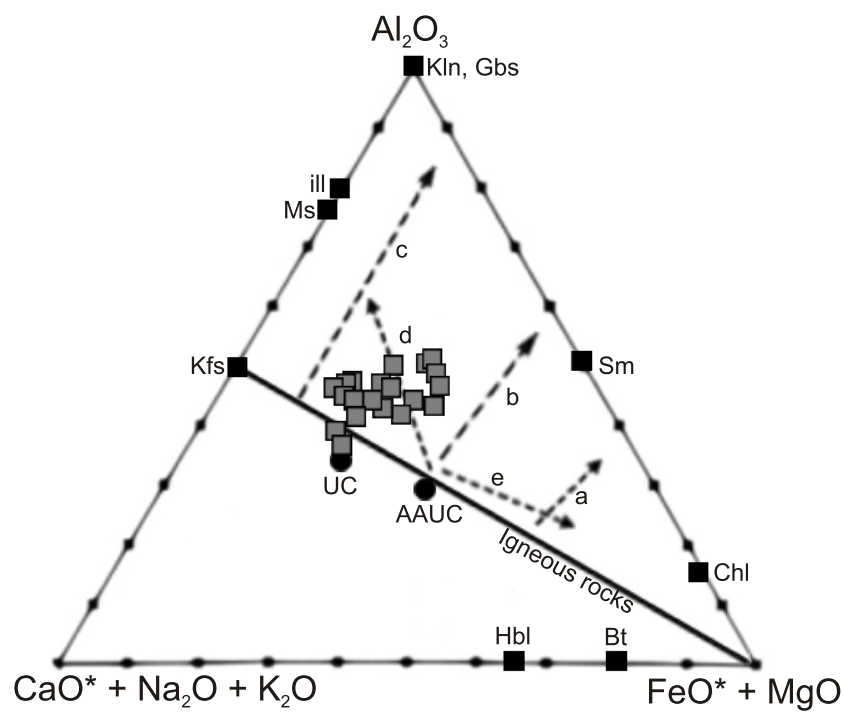

Fig. 7. A-CNK-FM ternary diagram (mol \%) showing composition of the Bozeş sediments

(after Nesbitt and Young, 1982)

Compositions of average Archean upper crust (AAUC) and average upper crust (UC), respectively, are after Taylor and McLennan (1985); trends are shown for idealized weathering of (a) basalts, (b) AAUC, (c) granodiorites and granites, as well as (d) K-metasomatism and (e) Mg-metasomatism trends; other explanations as in Figure 6 
such as REEs, $\mathrm{Hf}, \mathrm{Ti}, \mathrm{Cr}$, Co, $\mathrm{Zr}, \mathrm{Nb}, \mathrm{Y}$, Th and $\mathrm{Sc}$, is preserved in sedimentary rocks through weathering processes, because of their relative immobility (Taylor and McLennan, 1985). In the case of Bozeş siliciclastic rocks, our data support the assertion that moderate to severe chemical weathering prior to sedimentation resulted in at least moderately mature rocks, later affected by diagenesis processes, thus major oxides and relatively mobile elements are not further considered as discriminating factors for determining the provenance and discussing the tectonic setting of these sedimentary rocks.

Lithic clasts are among the best proxies for identifying the composition of the detrital sources. For the Bozeş sedimentary rocks, metamorphic and volcanic rocks are potential source rocks. More precisely, the metamorphic source is likely represented by a metasedimentary unit, as revealed by the consistent quantity of quartzite clasts, together with the few micaschist and gneiss fragments.

These two types of detrital sources are further supported by the trace element geochemistry. An arc with a dominantly felsic composition has a La/Th ratio that is rather low $(<5)$ and uniform, while its $\mathrm{Hf}$ content varies between 3 and 7 ppm. Progressive unroofing of the arc and/or incorporation of sedimentary basement rocks will increase the $\mathrm{Hf}$ content due to the release of zircon (Floyd and Leveridge, 1987). The Bozeş sandstones have La/Th ratios of 2.2 to 3.8 (Appendix 2), revealing the influence of a magmatic arc situated in close vicinity. $A \mathrm{La} / \mathrm{Th}$ versus $\mathrm{Hf}$ plot can provide information regarding the degree of recycling and the provenance of the sandstones (Floyd and Leveridge, 1987; Floyd et al., 1991; Fig. 8A). The composition of the Bozeş sedimentary rocks suggests a high contribution from a felsic arc source, with some zircon input, which might result through erosion of a (meta)sedimentary unit.

Recycling of the sediments can be evaluated using elements such as Th, Sc and $\mathrm{Zr}$ (McLennan et al., 1993), as Th/Sc ratio is very sensitive to compositional variations associated with the provenance area (McLennan et al., 1990), while the $\mathrm{Zr} / \mathrm{Sc}$ ratio can monitor sedimentary recycling processes, due to the resistance of zircon to chemical weathering and erosion. A simple positive correlation between these two ratios is characteristic of first-cycle sediments, while for recycled sediments the $\mathrm{Zr} / \mathrm{Sc}$ ratio varies considerably in contrast to a smaller variation of the Th/Sc ratio (McLennan et al., 1993). On the Th/Sc versus $\mathrm{Zr} / \mathrm{Sc}$ plot (McLennan et al., 1993; Fig. 8B), the Bozeş sandstones form a tight cluster close to the compositional trend from mantle to upper continental crust, but very close to and displaying a tendency towards the sediment recycling trend. This may indicates that, in the case of the Bozes siliciclastic rocks, the provenance was not controlled exclusively by the source composition, and, aside from the first cycle sediments provided through erosion of a continental crustal source, detrital material resulting from erosion of an old (meta)sedimentary source is implied.

Thorium is incompatible during magmatic crystallisation (Taylor and McLennan, 1985), concentrating in late-formed phases in igneous rocks, while scandium is compatible and is found disseminated in mafic minerals. Fedo et al. (1997) have shown that the sorting process does not affect $\mathrm{Th} / \mathrm{Sc}$ ratios. Therefore, $\mathrm{Th} / \mathrm{Sc}$ ratio has been widely used to assess the composition of the sediment supplier. In the case of the Bozeş sedimentary rocks, Th/Sc ratio varies between 0.31 and 1.12 (Appendix 2), but is generally less than one (with only two exceptions) indicating possible contribution from a mafic source (McLennan et al., 1993).

Chromium is a very useful trace element in identifying accessory detrital minerals (e.g., chromite), which are mainly
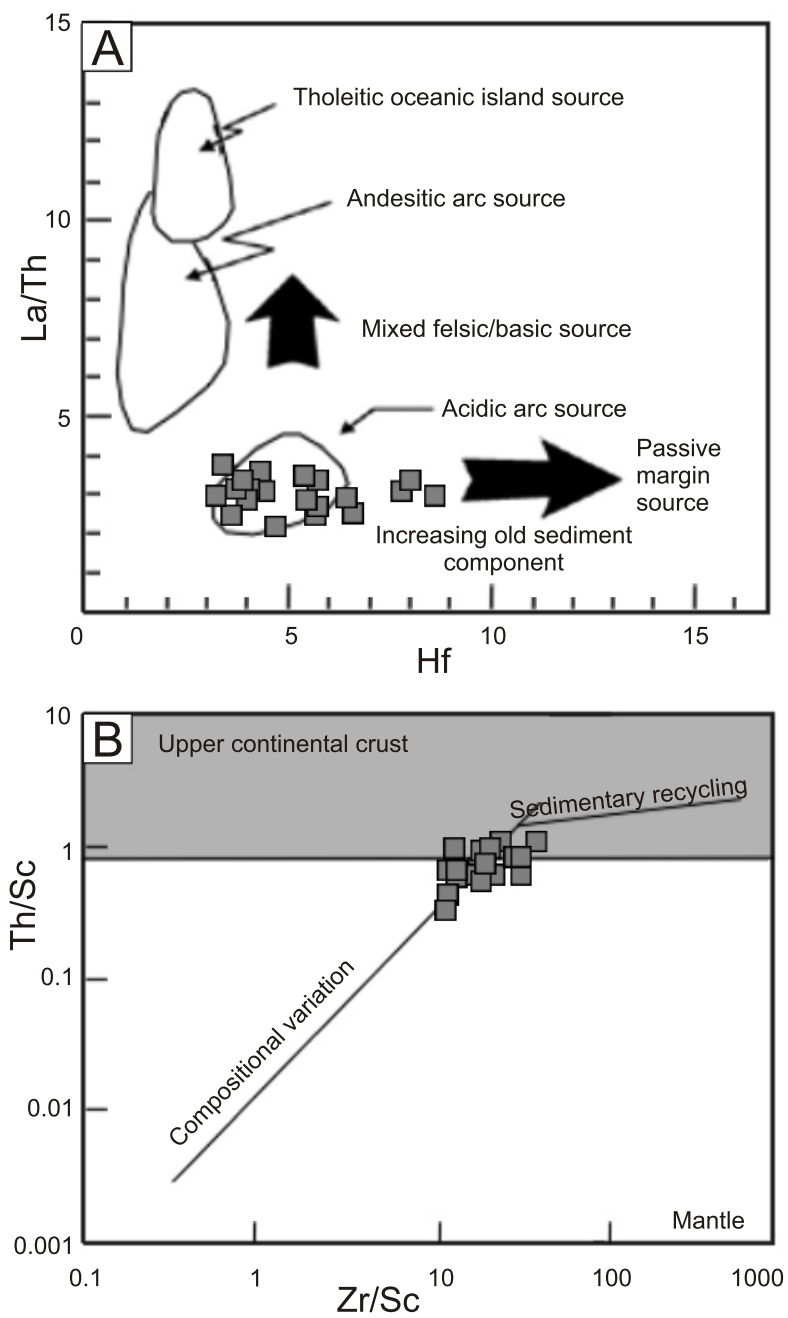

Fig. 8. Diagrams for discriminating the source and intra-basin sediment recycling of the Bozes sedimentary rocks (A) after Floyd and Leveridge (1987), (B) after McLennan et al. (1993)

hosted by mafic and ultramafic sources, such as ophiolites. The $\mathrm{Cr}$ content of the Bozeş samples varies between 23.95 and $196.4 \mathrm{ppm}$, in some cases exceeding the average $\mathrm{Cr}$ content of the upper continental crust (83 ppm, McLennan, 2001). Such enrichment in $\mathrm{Cr}$ may suggest some input of mafic and ultramafic materials from the source area. However, mafic sources would also cause enrichment of $\mathrm{Ni}$ and $\mathrm{V}$, but, with very few exceptions (three samples for $\mathrm{Ni}$ and one for $\mathrm{V}$ ), the Bozes sediments have values below those of the UCC (44 ppm for Ni and $107 \mathrm{ppm}$ for V; McLennan, 2001). From the outliers, only one sample (1-VIN; $196.36 \mathrm{ppm}$ for $\mathrm{Cr}, 122.55 \mathrm{ppm}$ for $\mathrm{V}$ and $57.82 \mathrm{ppm}$ for $\mathrm{Ni}$ ) shows enrichment in all three ferromagnesian trace elements $\mathrm{Cr}, \mathrm{Ni}$ and $\mathrm{V}$, as compared to UCC values, and may have some true mafic components. For the other two, their extremely high $\mathrm{Ni}$ content (of 245.29 and $2827.99 \mathrm{ppm}$ ) is not correlated with equivalent high $\mathrm{Cr}$ or $\mathrm{V}$ amounts. As the mineralogical content of the samples (including the heavy mineral assemblage, Pojar et al., 2014) do not reveal any particular feature, no plausible explanation for such extreme $\mathrm{Ni}$ values has been found up to now.

The trace element geochemical content of the Bozes sandstones, combined with the type and abundances of lithic clasts, is indicative of derivation by erosion and weathering of a volca- 
nic arc, with some contributions through recycling of an existing quartzose metasedimentary source. Very small inputs from a mafic-ultramafic source are possible.

\section{IMPLICATION FOR TECTONIC SETTING OF DEPOSITION}

Besides constraining source rocks, geochemical parameters have been applied to establishing the tectonic setting of detrital sedimentary rocks (Bhatia, 1983; Roser and Korsch, 1985, 1986, 1988; Bhatia and Crook, 1986). However, as mentioned certain elements (e.g., $\mathrm{Na}, \mathrm{K}$ ) are highly mobile during depositional processes, and thus they have to be avoided in discriminating the tectonic setting of deposition, certain trace elements considered as relatively immobile being favoured instead (Taylor and McLennan, 1985). Based on trace elements considered as relatively immobile, discrimination diagrams were established using actual depositional settings, and show some limitations when applied to ancient sedimentary rocks (Ryan and Williams, 2007), irrespective of the elements employed. Also, specific tectonic settings do not necessarily produce rocks with unique geochemical signatures (Bahlburg, 1998). Therefore, when assessing the tectonic setting, caution is needed.

Various tectonic discrimination diagrams based on trace elements were developed by Bhatia and Crook (1986), allowing clear differentiation among the four tectonic settings considered to be the most common sites of greywacke deposition: oceanic island arc, continental island arc, active continental margin and passive margin. The Bozeş samples are clearly grouped in the continental island arc field in the ternary diagrams La-Th-Sc or Th-Co-Zr/10 (Fig. 9) of Bhatia and Crook (1986). Thus, deposition of the Bozeş sandstones most probably took place on a convergent margin in a continental volcanic arc setting. This includes sedimentary basins located in the apical inter-arc, back-arc and fore-arc environments of volcanic arcs developed over thin continental crust, as defined by Bhatia and Crook (1986).

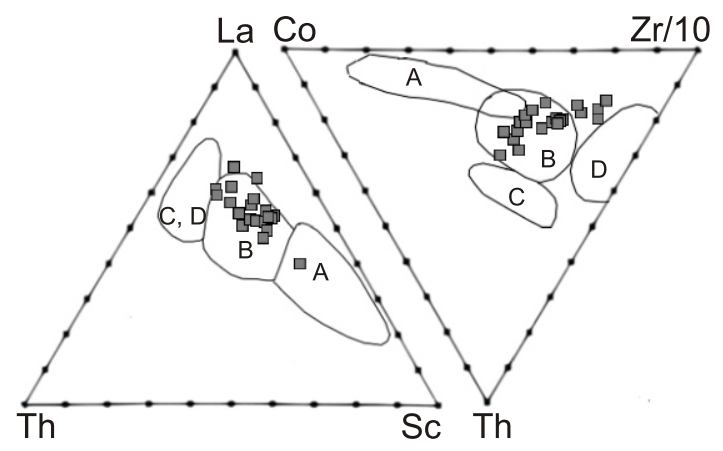

Fig. 9. Tectonic setting discrimination diagrams for the Bozeş sedimentary rocks based on trace elements (after Bhatia and Crook, 1986)

A - oceanic island arc, B - continental island arc, C - active continental margin, $\mathrm{D}$ - passive margin

\section{COMPARISON AND INTEGRATION WITH OTHER PROVENANCE INDICATORS}

According to the whole-rock geochemical data, the sedimentary material of the Bozeş basin was provided mainly through erosion of sources with intermediate-felsic composition, a metasedimentary basement and a volcanic arc. During transport, the material was weakly sorted, but somewhat altered, the sedimentary material studied being generally moderately mature. This suggests a short transport distance from the eroded sources. Deposition took place on a convergent margin.

But reconstructing the provenance of any sedimentary deposit requires an integrated approach of several analytical techniques (e.g., Weltje and von Eynatten, 2004). Thus, the provenance results based on geochemical compositions have to be compared and, if possible, integrated with previous interpretations, e.g. heavy minerals or rock framework composition.

\section{PROVENANCE COMPONENTS FOR BOZEŞ SEDIMENTARY ROCKS}

Heavy mineral assemblages as provenance indicators have already been used in constraining the rock types and tectonic units which acted as potential sources for the Bozeş sediments. According to Pojar et al. (2014), the spectra of heavy minerals are dominated by garnet (20.7 and $84.7 \%$ from the heavies) which, together with a lower quantity of epidote (up to $11.2 \%$ ) and scarce staurolite, represent between 35 and $90 \%$ of the heavy phases, and point towards a unit metamorphosed up to amphibolite facies as the main source. The large quantity of rounded zircon provided additional support for a mature, recycled sedimentary source, possible the same metamorphic unit, while euhedral crystals of zircon, of which some are very elongated ones, are specific for magmatic deposits (Pojar et al., 2014). The heavy mineral spectra reveal a much more consistent contribution from a metamorphic source, most probably a metasedimentary unit as constrained by geochemical and petrographic investigations, compared with input from a magmatic arc.

The QFL and QmFLt diagrams may contradict the provenance interpretation based on geochemical contents, as discussed by Weltje (2006) and reported in other studies (e.g., Mader and Neubauer, 2004; Kutterolf et al., 2008). For the Bozeş unit, the provenance interpretation based on framework rock composition follows the geochemical provenance constraints as regards the two types of clastic suppliers, i.e. a mature, recycled sedimentary source and a felsic, magmatic arc (Fig. 3). However, according to the modal composition, quantitatively, the old sedimentary unit seems to have a larger detrital contribution than the magmatic arc.

The results of the analytical techniques employed for the Bozeş siliciclastic rocks, i.e. whole-rock geochemistry, modal distribution and heavy minerals spectra, from both this study and the literature (Antonescu et al., 1963; Suciu-Krausz et al., 2006), are consistent in constraining the two major types of detrital suppliers. However, there are differences as regards the quantitative estimations of different source contributions to the 
basin fill. The framework mineralogy and heavy minerals data suggest a larger contribution of the metasedimentary basement than that of the magmatic arc. By contrast, the geochemical composition favours the arc as the major detrital provider, but does not exclude a consistent contribution from the metamorphic unit. Such contradictory results are possible when combined methods are used (see the discussion of Kutterolf et al. 2008). No method alone can be considered as the most accurate; therefore it is also difficult to decide which quantitative provenance is the most probable, at least at the moment.

\section{SOURCE AREA AND GEODYNAMIC SETTING OF THE BOZES SEDIMENTARY BASIN}

Based on the identified erosional structures on the sandstone surfaces (such as groove, flute or deltoidal casts), as well as the petrography of the coarser siliciclastic rocks, an E-W dominant transport direction of the detrital material (in the present-day coordinates) was proposed by Antonescu et al. (1963) and Dimian and Popa-Dimian (1964). The first authors also mentioned a subordinate $\mathrm{W}-\mathrm{E}$ direction, a hypothesis not sustained by the later authors. However, they interpreted the Bozeş area as the deepest part of the geosyncline, which was filled with sediments provided by the nearby Transylvanian hinterland.

The Transylvanian basement is a stack of basement-involved thrust sheets, which were assembled by the Mid-Cretaceous, consisting of Paleozoic crystalline units, ophiolites and island-arc volcanic rocks, and a sedimentary cover of a Triassic to mid-Cretaceous age (Krézsek and Bally, 2006 and references therein). Deep erosion of crystalline nappes beyond the Late Cretaceous depositional areas, suggesting major pre-Late Cretaceous uplift and exhumation (Krézsek and Bally, 2006) was supported by fission-track studies (e.g., Dallmeyer et al., 1999) and seismic interpretation (Krézsek and Bally, 2006). The provenance indicators are in agreement with such a tectonic unit, although the fingerprint of the ophiolitic sources is difficult to constrain by heavy mineral concentrates (Pojar et al., 2014), as ultramafic mineral indicators are sensitive to diagenetic dissolution. However, a moderate input is corroborated by the various geochemical proxies. It might be that the Cr-bearing minerals are present as a minor constituent in the very fine fraction (<60 $\mu \mathrm{m}$; Zimmermann and Bahlburg, 2003).

Basin modelling using vitrinite reflectance data on the Bozeş flysch strata recorded a maximum thickness of about $7000 \mathrm{~m}$ with very low heat-flow values, was interpreted as indicating an ocean trench basin setting for the Bozeş sediments (Schuller, 2004; Schuller et al., 2009). This hypothesis is not in agreement with the setting constrained by the geochemical data, nor was sustained by other authors, based on tectonic arguments (e.g., Csontos and Vörös, 2004; Schmid et al., 2008, Kounov and Schmid, 2013). However, the depositional setting, as well as the palaeogeographical position, are still a matter of debate, and require studies on a larger regional scale.

\section{CONCLUSIONS}

A whole-rock geochemical investigation of sandstones was carried out to constrain the provenance and tectonic setting of the Upper Cretaceous Bozeş Formation. Using geochemical data, it was possible to categorize the sedimentary rocks as litharenites and greywackes, the rocks being immature to moderately mature. This is due to the weathering of source rocks and to the low degree of sorting and alteration during transport, with only post-depositional K-metasomatism affecting the detrital material. The provenance interpretation based on geochemical composition was compared and integrated with other provenance indicators, such as the framework rock composition and heavy mineral spectra. Two major source types, a felsic magmatic arc and a mature, recycled metasedimentary basement, were constrained. These source types are consistent with the Transylvanian basement as the major supply area, which was uplifted, exhumed and intensely eroded. The depositional setting is suggested to be on a convergent margin, in connection with a volcanic arc developed over thin continental crust, although this hypothesis contradicts other ideas, and further studies are necessary to clarify this tectonic question.

The present study reveals the importance of applying several analytical techniques to establish the provenance of a sedimentary succession. The various methods involved may give complementary and/or contradictory results, thus offering a better control on the data and increasing the accuracy of provenance interpretation.

Acknowledgements. The financial support of the project POSDRU/159/1.5/S/133391 (Sectorial Operational Programme for Human Resources Development 2007-2013, co-financed by the European Social Fund) and of the project PN II-RU-TE 313/2010 (CNCSIS-UEFISCSU, Romanian Ministry of Education and Research) is acknowledged. Assoc. Prof. F. Koller (University of Vienna, Austria) is thanked for facilitating the sample preparation and analysis. We greatly appreciate constructive and helpful reviews by D. Salata and M. Vd'ačný that considerably improved this manuscript.

\section{REFERENCES}

Antonescu, E.M., Bals, F., Georgescu, F., Georgescu, V., Mantea, G., Mihăilescu, N., Panin, N., Tomescu, C., 1963 Données sedimentologique sur les depots sénoniens-daniens de la region de Viţnu de Jos-Geoagiu (in Romanian with French summary). Studii şi Cercetări Geologice, 8: 215-234.

Bahlburg, H., 1998. The geochemistry and provenance of Ordovician turbidites in the Argentine Puna. Geological Society Special Publications, 142: 127-142.

Balintoni, I., 1994. Structure of the Apuseni Mountains. Romanian Journal of Tectonics and Regional Geology, 75: 51-58.

Balintoni, I., 1997. Geotectonica terenurilor metamorfice din România (in Romanian). Ed. Carpatica, Cluj Napoca.
Balintoni, I., Balica, C., Cliveți, M., Li, Q-L., Hann, H.P., Chen, F., Schuller, V., 2009. The emplacement age of the Muntele Mare Variscan granite (Apuseni Mountains, Romania). Geologica Carpathica, 60: 495-504

Bălc, R., Suciu-Krausz, E., Borbei, F., 2007. Biostratigraphy of the Cretaceous deposits in the Western Transylvanides from Ampoi Valley (Southern Apuseni Mountains, Romania). Studia Universitatis Babeş-Bolyai, Geologia, 52: 37-43.

Bălc, R., Sylie, L., Zaharia, L., 2012. Calcareous nannofossils and sedimentary facies in the Upper Cretaceous Bozes Formation (Southern Apuseni Mountains, Romania). Studia Universitatis Babeş-Bolyai, Geologia, 57: 23-32. 
Bhatia, M.R., 1983. Plate tectonics and geochemical composition of sandstones. Journal of Geology, 91: 611-627.

Bhatia, M.R., Crook, K.A.W., 1986. Trace element characteristics of graywackes and tectonic setting discrimination of sedimentary basins. Contributions to Mineralogy and Petrology, 92 181-193.

Bleahu, M., Bordea, S., Lupu, M., Ştefan, A., Patrulius, D., Panin, S., 1981. The structure of the Apuseni Mountains. Guide to Excursion B3, Carpatho-Balkan Geological Association XII Congress of Geology and Geophysics.

Camiré, G.E., Laflèche, M.R., Ludden, J. 1993. Archaean metasedimentary rocks from the northwestern Pontiac Subprovince of the Canadian Shield: chemical characterization, weathering and modeling of the source areas. Precambrian Research, 62: 285-305.

Condie, K.C., 1993. Chemical composition and evolution of the upper continental crust: contrasting results from surface samples and shales. Chemical Geology, 104: 1-37.

Csontos, L., Vörös, A., 2004. Mesozoic plate tectonic reconstruction of the Carpathian region. Palaeogeography, Palaeoclimatology, Palaeoecology, 210: 1-56.

Cullers, R.L., 2000. The geochemistry of shales, siltstones and sandstones of Pennsylvanian-Permian age, Colorado, USA implications for provenance and metamorphic studies. Lithos, 51: 181-203.

Cullers, R.L., Barrett, T., Carlson, R., Robinson, B., 1987. Rare earth element and mineralogic changes in Holocene soil and stream sediment: a case study in the West Mountains, Colorado, U.S.A. Chemical Geology, 63: 275-297.

Cullers, R.L., DiMarco, M.J., Lowe, D.R., Stone, J., 1993. Geochemistry of a silicified, felsic volcaniclastic suite from the early Archaean Panorama Formation, Pilbara Block, Western Australia: an evaluation of depositional and post-depositional processes with special emphasis on the rare-earth elements. Precambrian Research, 60: 99-116.

Dallmeyer, R.D., Pană, D.I., Neubauer, F., Erdmer, P., 1999. Tectonothermal evolution of the Apuseni Mountains, Romania: resolution of Variscan versus Alpine events with ${ }^{40} \mathrm{Ar} /{ }^{39} \mathrm{Ar}$ ages. Journal of Geology, 107: 329-352.

Dickinson, W.R., 1970. Interpreting detrital modes of greywacke and arkose. Journal of Sedimentary Petrology, 40: 695-702.

Dickinson, W.R., 1985. Interpreting provenance relations from detrital modes of sandstones. In: Provenance of Arenites (ed. G.G. Zuffa): 333-361. Reidel, Dordrecht.

Dickinson, W.R., Suczek, C.A., 1979. Plate tectonics and sandstone compositions. AAPG Bulletin, 63: 2164-2182.

Dimian, E., Popa-Dimian, M., 1964. Date stratigrafice şi sedimentologice privind formatiunile cretacice dintre Valea Mureşului şi Valea Ampoiului (in Romanian). Dări de Seamă ale Institutului de Geologie, 50: 107-126.

Fedo, C.M., Nesbitt, H.W., Young, G.M., 1995. Unravelling the effects of potassium metasomatism in sedimentary rocks and paleosoils, with implications for paleoweathering conditions and provenance. Geology, 23: 921-924.

Fedo, C.M., Young, G.M., Nesbitt, H.W., Hanchar, J.M., 1997. Potassic and sodic metasomatism in the Southern Province of the Canadian Shield: evidence from the Paleoproterozoic Serpent Formation, Huronian Supergroup, Canada. Precambrian Research, 84: 17-36.

Floyd, P.A., Leveridge, B.E., 1987. Tectonic environment of the Devonian Gramscatho basin, south Cornwall: framework mode and geochemical evidence from turbiditic sandstones. Journal of the Geological Society, 144: 531-542.

Floyd, P.A., Shail, R., Leveridge, B.E., Franke, W., 1991. Geochemistry and provenance of Rhenohercynian synorogenic sandstones: Implications for tectonic environment discrimination. Geological Society Special Publications, 57:173-188.

Ghiţulescu, T.P., Socolescu, M., 1941. Etude géologiques et minière des Monts Métallifères. Anuarul Institutului Geologic, 21: 181-463.

Harnois, L., 1988. The CIW index: a new chemical index of weathering. Sedimentary Geology, 55: 319-322.
Ingersoll, R.V., Bullard, T.F., Ford, R.L., Grimm, J.P., Pickle, J.D., Sares, S.W., 1984. The effect of grain size on detrital modes: a test of the Gazzi-Dickinson point-counting method. Journal of Sedimentary Petrology, 54:103-116.

Kelley, K.A., Plank, T., Ludden, J., Staudigel, H., 2003. Composition of altered oceanic crust at ODP Sites 801 and 1149. Geochemistry, Geophysics, Geosystems, 4: 1-21.

Kounov, A., Schmid, S.M., 2013. Fission-track constraints on the thermal and tectonic evolution of the Apuseni Mountains (Romania). International Journal of Earth Sciences, 102: 207-233.

Krézsek, C., Bally, A.W., 2006. The Transylvanian Basin (Romania) and its relation to the Carpathian fold and thrust belt: Insights in gravitational salt tectonics. Marine and Petroleum Geology, 23: 405-442.

Kutterolf, S., Diener, R., Schacht, U., Krawinkel, H., 2008. Provenance of the Carboniferous Hochwipfel Formation (Karawanken Mountains, Austria/Slovenia) - geochemistry versus petrography. Sedimentary Geology, 203: 246-266.

Long, X., Sun, M., Yuan, C., Xiao, W., Cai, K., 2008. Early Paleozoic sedimentary record of the Chinese Altai: implications for its tectonic evolution. Sedimentary Geology, 208: 88-100.

Mader, D, Neubauer, F., 2004. Provenance of Palaeozoic sandstones from the Carnic Alps (Austria): petrographic and geochemical indicators. International Journal of Earth Sciences, 93: 262-281.

Marincaş, V., 1973. The age of Bozeş Beds (in Romanian with English summary). Studia Universitatis Babeş-Bolyai, Geologia, 1: 39-46.

Marincaş, V., Mânecan, D., 1971. Contributions à la stratigraphie du Crétacé superiéur dans la région de Geoagiu. Sargetia, 8: 21-37.

McDonough, W.F., Sun, S.S., 1995. The composition of the Earth. Chemical Geology, 120: 223-253.

McLennan, S.M., 1989. Rare earth elements in sedimentary rocks: Influence of provenance and sedimentary processes. Reviews in Mineralogy, 21: 169-200.

McLennan, S.M., 1993. Weathering and global denudation. Journal of Geology, 101: 295-303.

McLennan, S.M., 2001. Relationships between the trace element composition of sedimentary rocks and upper continental crust. Geochemistry, Geophysics, Geosystems, 2:1021-1045.

McLennan, S.M., Taylor, S.R., 1991. Sedimentary rocks and crustal evolution: tectonic setting and secular trends. Journal of Geology, 99: 1-21.

McLennan, S.M., Taylor, S.R., Eriksson, K.A., 1983. Geochemistry of Archaean shales from the Pilbara Supergroup, Western Australia. Geochimica et Cosmochimica Acta, 47: 1211-1222.

McLennan, S.M., Taylor, S.R., McCulloch, M.T., Maynard, J.B., 1990. Geochemical and Nd-Sr isotopic composition of deep-sea turbidites: crustal evolution and plate tectonic associations. Geochimica et Cosmochimica Acta, 54: 2015-2050.

McLennan, S.M., Hemming, S., McDaniel, D.K., Hanson, G.N., 1993. Geochemical approaches to sedimentation, provenance and tectonics. GSA Special Paper, 284: 21-40.

McLennan, S.M., Bock, B., Hemming, S., Hurowitz, J.A., Lev, S.M., McDaniel, D.K., 2003. The roles of provenance and sedimentary processes in the geochemistry of sedimentary rocks. Geological Association of Canada, GeoText, 4: 7-38.

Nesbitt, H.W., Young, G.M., 1982. Early Proterozoic climates and plate motions inferred from major element chemistry of lutites. Nature, 299: 715-717.

Nesbitt, H.W., Young, G.M., 1984. Prediction of some weathering trends of plutonic and volcanic rocks based on thermodynamic and kinetic considerations. Geochimica et Cosmochimica Acta, 48: 1523-1534.

Nesbitt, H.W., Young, G.M., 1989. Formation and diagenesis of weathering profiles. Journal of Geology, 97: 129-147.

Nesbitt, H.W., Young, G.M., 1996. Petrogenesis of sediments in the absence of chemical weathering: effects of abrasion and sorting on bulk composition and mineralogy. Sedimentology, 43: 341-358. 
Pettijohn, F.H., Potter, P.E., Siever, R., 1972. Sand and Sandstone. Springer, New York.

Pojar, I., Zaharia, L., Benea, M., 2014. Heavy mineral distributions in Upper Cretaceous Bozes Formation (Apuseni Mountains, Romania) - implications for sediment provenance. Carpathian Journal of Earth and Environmental Sciences, 9: 125-132.

Roser, B.P., Korsch, R.J., 1985. Plate tectonics and geochemical composition of sandstones: a discussion. Journal of Geology, 93: 81-84.

Roser, B.P., Korsch, R.J., 1986. Determination of tectonic setting of sandstone-mudstone suites using $\mathrm{SiO}_{2}$ content and $\mathrm{K}_{2} \mathrm{O} / \mathrm{Na}_{2} \mathrm{O}$ ratio. Journal of Geology, 94: 635-650.

Roser, B.P., Korsch, R.J., 1988. Provenance signatures of sandstone-mudstone suites determined using discriminant function analysis of major-element data. Chemical Geology, 67: 119-139.

Roser, B.P., Cooper, R.A., Nathan, S., Tulloch, A.J., 1996. Reconnaissance sandstone geochemistry, provenance, and tectonic setting of the lower Paleozoic terraines of the West Coast and Nelson, New Zealand. New Zealand Journal of Geophysics, 39 $1-16$.

Ryan, K.M., Williams, D.M., 2007. Testing the reliability of discrimination diagrams for determining the tectonic depositional environment of ancient sedimentary basins. Chemical Geology, 242: $103-125$.

Săndulescu, M., 1975. Essai de synthèse structuraux des Carpathes. Bulletin de la Societé Géologique de France, 17: 299-358.

Săndulescu, M., 1984. Geotectonica României (in Romanian). Ed. Tehnică, Bucharest.

Săndulescu, M., 1994. Overview on Romanian Geology. Romanian Journal of Tectonics and Regional Geology, 75: 3-15.

Schmid, S.M., Bernoulli, D., Fügenschuh, B., Maţenco, L., Schefer, S., Schuster, R., Tischler, M., Ustaszewski, K., 2008. The Alpine-Carpathian-Dinaridic orogenic system: correlation and evolution of tectonic units. Swiss Journal of Geosciences, 101: 139-183.

Schuller, V., 2004. Evolution and geodynamic significance of the Upper Cretaceous Gosau basin in the Apuseni Mountains (Romania). Tübinger Geowissenschaftliche Arbeiten, A70.

Schuller, V., Frisch, W., Danišik, M., Dunkl, I., Melinte, M.C. 2009. Upper Cretaceous Gosau deposits of the Apuseni Mountains (Romania) - similarities and differences to the Eastern Alps. Austrian Journal of Earth Sciences, 102: 133-145.

Suciu-Krausz, E., Bălc, R., Borbei, F., 2006. New data on the Western Transylvanides along Ampoi Valley (Southern Apuseni
Mts., Romania). Studia Universitatis Babeş-Bolyai, Geologia, 51: 55-60.

Taylor, S.R., McLennan, S.M., 1985. The Continental Crust: Its Composition and Evolution. Blackwell, London.

Tomescu, C., Panin, Ş., Georgescu, F., Mantea, G., Antonescu, E., 1969. Contribution à la connaissance des dépôts néo-crétaces dans les Monts Apuseni de Sud (in Romanian with French summary). Studii şi Cercetări de Geologie, Geofizică, Geografie (Geol.), 14: 239-252.

Van Kranendonk, M.J., 2006. Volcanic degassing, hydrotherma circulation and the flourishing of early life on Earth: new evidence from the Warrawoona Group, Pilbara Craton, Western Australia. Earth-Science Reviews, 74: 197-240.

Von Eynatten, H., Gaupp, R., 1999. Provenance of Cretaceous synorogenic sandstones in the Eastern Alps: constraints from framework petrography, heavy mineral analysis and mineral chemistry. Sedimentary Geology, 124: 81-111.

Weltje, G.J., 2006. Ternary sandstone composition and provenance: an evaluation of the "Dickinson model". Geological Society Special Publications, 264: 79-99.

Weltje, G.J., von Eynatten, H., 2004. Quantitative provenance analysis of sediments: review and outlook. Sedimentary Geology, 171: 1-11.

Williams, I.S., Krzemińska, E., Wiszniewska, J., 2009. An extension of the Svecofennian orogenic province into NE Poland: evidence from geochemistry and detrital zircon from Paleoproterozoic paragneisses. Precambrian Research, 172 234-254.

Willingshofer, E., Neubauer, F., Cloetingh, S., 1999. The significance of Gosau-type basins for the Late Cretaceous tectonic history of the Alpine-Carpathian belt. Physical Chemical Earth (A), 24: 687-695.

Winchester, J.A., Patočka, F., Kachlík, V., Melzer, M., Nawakowski, C., Crowley, Q.G., Floyd, P.A., 2003. Geochemical discrimination of metasedimentary sequences in the Krkonoše-Jizera terrane (West Sudetes, Bohemian Massif): paleotectonic and stratigraphic constraints. Geologica Carpathica, 54: 267-280.

Wronkiewicz, D.J., Condie, K.C., 1987. Geochemistry of Archean shales from the Witwatersrand Supergroup, South Africa: source-area weathering and provenance. Geochimica et Cosmochimica Acta, 51: 2401-2416.

Zimmermann, U., Bahlburg, H., 2003. Provenance analysis and tectonic setting of the Ordovician deposits in the southern Puna basin, NW Argentina. Sedimentology, 50:1079-1104. 